\title{
EVALUATION OF FIFTEEN TOMATO GERMPLASM FOR SALT TOLERANCE
}

\author{
S. Nasrin', M.A. Mannan', M.M. Islam ${ }^{1}$, S.A.K.U. Khan ${ }^{1}$ and S.M.M. Rahman ${ }^{2}$ \\ ${ }^{1}$ Agrotechnology Discipline and ${ }^{2}$ Biotechnology and Genetic Engineering Discipline, Khulna University, \\ Khulna, Bangladesh \\ Corresponding E-mail: shamimakbd.seema@gmail.com
}

(Received: 16 August 2021, Accepted: 05 September 2021)

Keywords: Germplasm, Salinity, Salt, Tolerance and Tomato

\begin{abstract}
Soil salinity is a serious threat to crop productivity which influence growth and productivity of crop plants. Salt tolerance differ species to species and variety to variety. Therefore, this research work was initiated to investigate the influence of salinity levels on growth and yield of tomato genotypes and to select suitable variety for salt affected areas. A two factor poly house experiment was conducted in completely randomized design in Khulna University, Bangladesh, during November 2019 to March 2020. Factor one was consisted of fifteen tomato varieties including eight improved varieties developed by Bangladesh Agricultural Research Institute (BARI) and seven cultivars collected from farmer's field of Khulna region. Other factor was consisted of five levels of soil salinity viz. control, 4, 8, 12 and $16 \mathrm{dSm}^{-1}$. Tomato genotypes and salinity usages both significantly dissimilar for the agro- morphogenic traits. The plant height, leaf traits and yield traits are negatively influenced by salinity level. The local variety Guli gave the highest plant height for all the treatments. Tomato var. BARI tomato-15 produced the maximum fruit weight plant ${ }^{-1}$ at control followed by $4 \mathrm{dSm}^{-1}$ and $8 \mathrm{dSm}^{-1}$. Therefore, tomato var. BARI tomato- 15 may be suitable for cultivation in the areas containing salinity up to $8 \mathrm{dSm}^{-1}$. This may also help to further improve tomato cultivars in saline areas.
\end{abstract}

\section{Introduction}

Tomato (Solanum lycopersicum L.) belongs to the genus Solanum under the family Solanaceae. It is one of the most important vegetable crops in the world in terms of production and area under cultivation. It is a major source of vitamins and minerals such as vitamins A, B, C and calcium (Bose and Som, 1990). Lycopene in tomatoes is a phytochemical antioxidant that reduces the risk of cancer (Mutanen et al., 2011). In 2000, FAO estimated that 397 million hectares of land were affected by salinity and 434 million hectares by salinity (http://www.fao.org). It is likely that by 2050 , more than $50 \%$ of agricultural land will be lost to salinization due to poor fresh water irrigation and application of chemicals to the soil (Mahajan and Tuteja, 2005). Bangladesh has 2.86 million hectares of coastal and offshore land. Of which about 1.056 million hectares are affected by salinization to varying degrees (SRDI, 2010). The higher salinity level than the suggested level $(<700 \mu \mathrm{S} / \mathrm{cm})$ affecting both surface and ground water in south-west coastal region of Bangladesh (Shammi et al. 2016; Islam et. al., 2016). Salinity is becoming a major problem in the south-west coastal region of Bangladesh, where irrigation water quality is affected by intrusion salinity (Islam et al., 2018).

Soil salinity is the most important abiotic stress that hinders crop development and productivity (Ashraf and Wahed, 1993; Ahmad et al., 2019b). Salinity and drought are the main factors that hinder crop growth (Boyer, 1982). Salinity brings about physiological and metabolic changes that reduce crop yield (Pompeiano et al., 2016). Salinity affects plant morphology and reduces plant biomass content (Parvaiz, 2014). Tomato Plant growth is moderately sensitive to salinity depending on variety or 
growth stage (Estan et al., 2005). Tomato fruit yield and plant growth were not affected up to $2.6 \mathrm{dSm}^{-1}$ soil salinity of (Hassan et al., 1999). Plant height, main branches, flower clusters, fruit clusters, number of fruits, total fruit yield per plant, individual fruit weight, and amino acid content in leaves gradually decreased due to increasing salinity levels (Islam et al., 2011). The decrease in tomato yield due to salinity is due to the decrease in fruit number rather than fruit size ((Pengfei et al., 2017). In saline areas, cropping intensity is declined (62-114\%) compared to the national average (159\%) (Karim et al. 1990).

Therefore, this study was carried out to observe the effects of salinity on growth and yield parameters of tomato plants and identify the salinity tolerant variety for better yield under saline conditions among the fifteen variety.

\section{Materials and Methods}

A two-factor pot experiment was conducted under a poly shade house of Khulna University during November 2019 to March 2020. The experiment was laid out in Completely Randomized Design (CRD) with three replications. Treatments: Factor A : Fifteen tomato varieties including eight improved varieties developed by Bangladesh Agricultural Research Institute (BARI), namely BARI Tomato 2, BARI Tomato 8, BARI Tomato14, BARI Tomato15, BARI tomato16, BARI tomato17, BARI tomato18, BARI tomato19 and seven cultivars collected from farmers field of Khulna region namely Bonkim Ruby, Pusa Ruby. Suraksa, Patharkuchi, Ruma VF, Ruma 19 and Guli were used as plant material. The seeds of BARI tomato varieties were collected from Regional Agricultural Research Station (RARS), Jashore. Factor B: One control and four level of salinity was used as experimental treatment in this experiment. The treatments were $\mathrm{T}_{0}=$ control (without $\mathrm{NaCl}$ ), $\mathrm{T}_{1}=4 \mathrm{dSm}^{-1}, \mathrm{~T}_{2}=8 \mathrm{dSm}^{-}$ ${ }^{1}, \mathrm{~T}_{3}=12 \mathrm{dSm}^{-1}$ and $\mathrm{T}_{4}=16 \mathrm{dSm}^{-1}$.

The data were statistically analyzed by ANOVA using the MSTAT-C package program. Significance of differences between treatment means was evaluated using Duncan's New Multiple Range Test (Gomez and Gomez, 1984).

\section{Results and Discussion}

\section{Effect of Salinity on Plant Height}

The significantly highest plant height $(103.04 \mathrm{~cm})$ was found in the control, i.e. without salt, which was similar to that recorded in $4 \mathrm{dSm}-1(101.48 \mathrm{~cm})$ and the lowest plant height $(86.28 \mathrm{~cm})$ was recorded in $16 \mathrm{dSm}^{-1}$ (Figure 1a). The combined effect of cultivar and salinity level was also found significant in terms of plant height. The maximum plant height $(122.3 \mathrm{~cm})$ was recorded from the variety Guli with 4 $\mathrm{dSm}^{-1}$ salinity, which was statistically similar to Pusha Ruby with the control, and BARI tomato -19 with the control. The lowest plant height $(52.33 \mathrm{~cm})$ was observed in BARI tomato-2 with $16 \mathrm{dSm}^{-1}$ (Figure 2). This result is in conformity with Javed et al, (2002); Moniruzzaman et al., (2013) and Al Daej, (2018) they observed that the plant height decreased with increasing salinity level. Salinity affects plant growth by disturbing the water balance, causing an imbalance in plant nutrition and affecting plant physiological and biochemical processes (Yeo et al. 1985; Karim et al. 1993). Ahmad et al. (2019a) also state different genotypes showed variations against salinity stress. 

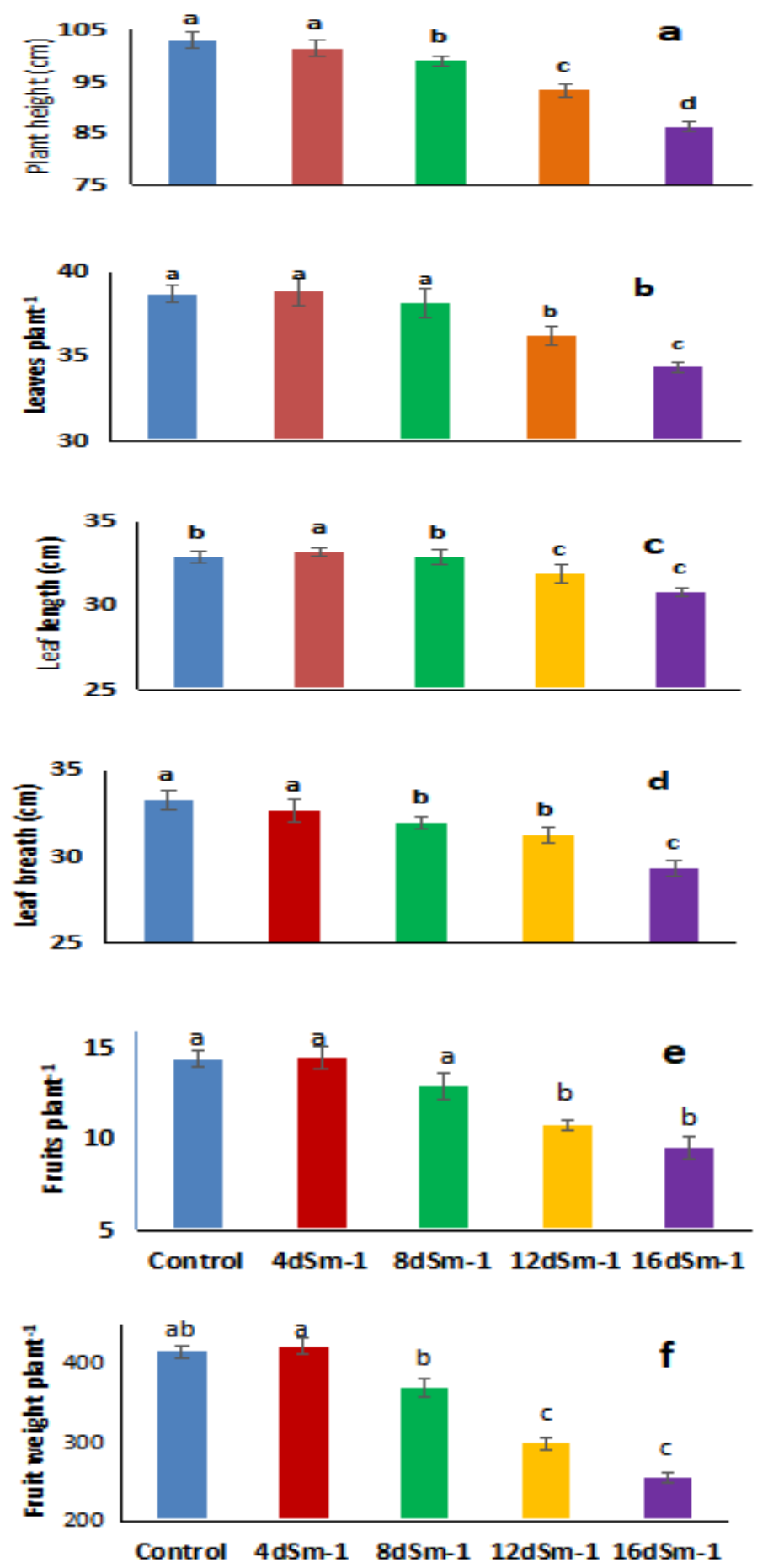

Fig. 1. Growth and Yield parameter influenced by different salinity level, a. Plant height, b. Leaves plant ${ }^{-1}$, c. Leaf length and d. Leaf breadth, e. Fruits plant ${ }^{-1}$ and f. Fruit weight plant ${ }^{-1}$ 

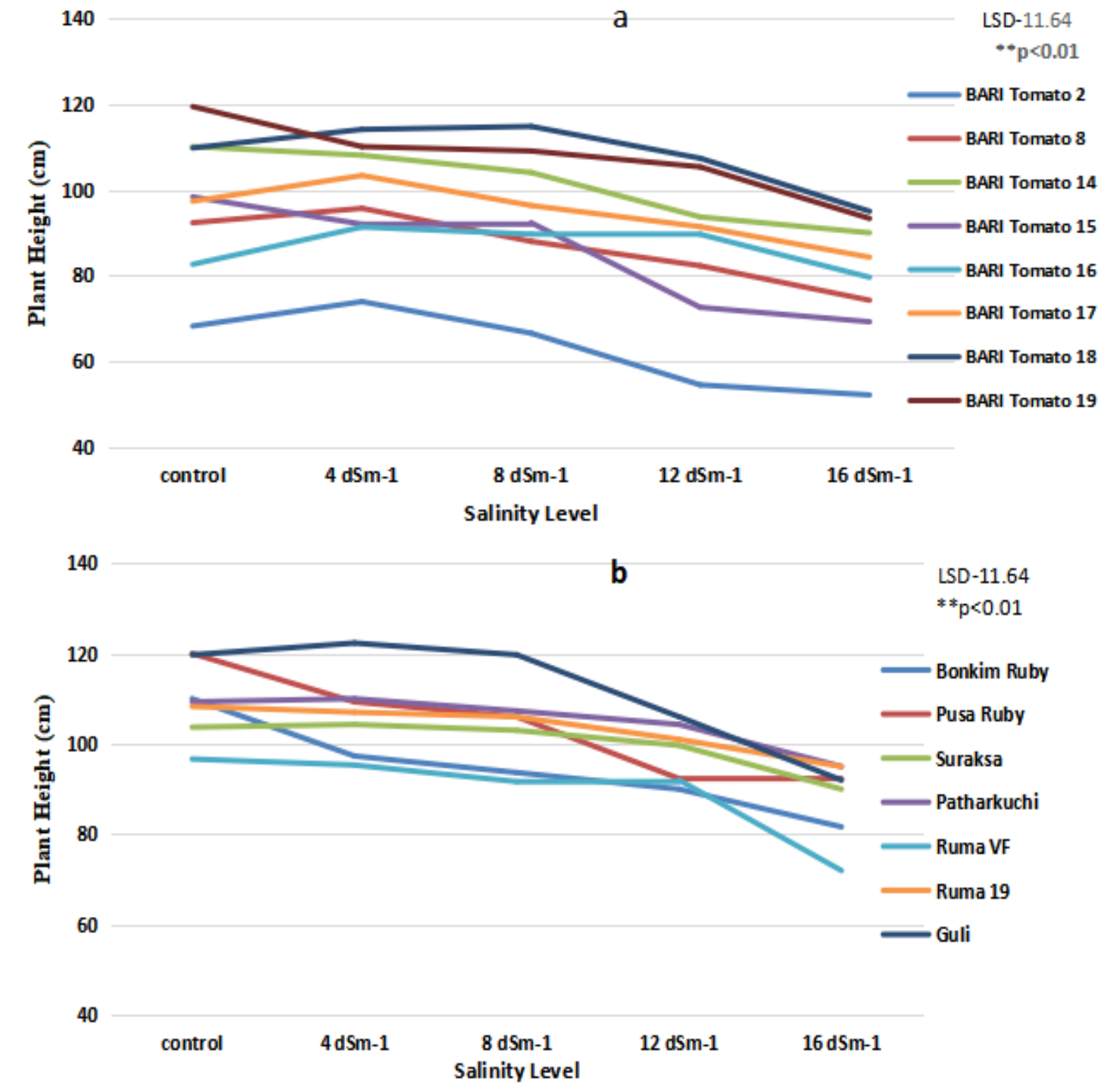

Fig. 2. Effect different levels of salinity on selected varieties of tomato in respect of plant height, a) BARI released variety, b) Local variety

\section{Effect of Salinity on Number of Leaves}

The maximum number of leaves (38.82) was found in $4 \mathrm{dSm}^{-1}$ which was statistically similar to the control (38.69) and the lowest number of leaves (34.35) was found in $16 \mathrm{dSm}^{-1}$ (Figure 1b). The combined effect of cultivar and salinity level was also found significant in terms of number of leaves. The maximum number of leaves (46) was recorded from the variety Guli with the control that was statistically similar to variety with the $4 \mathrm{dSm}^{-1}$ and Ruma-19, Ruma VF and BARI Tomato -14 with the control and $4 \mathrm{dSm}^{-1}$. The minimum number of leaves (28.56) was found in BARI Tomato -8 with 16 $\mathrm{dSm}^{-1}$ (Figure 3). Yadav et al. (2003) and Umar et al. (Al. (2018) also indicated that the number of leaves plant ${ }^{-1}$ was reduced under high salinity conditions. In addition, Al Daej, (2018) and Rahman et $\mathrm{al}$, (2018) was found significant differences in the response of different tomato cultivars to salinity. 

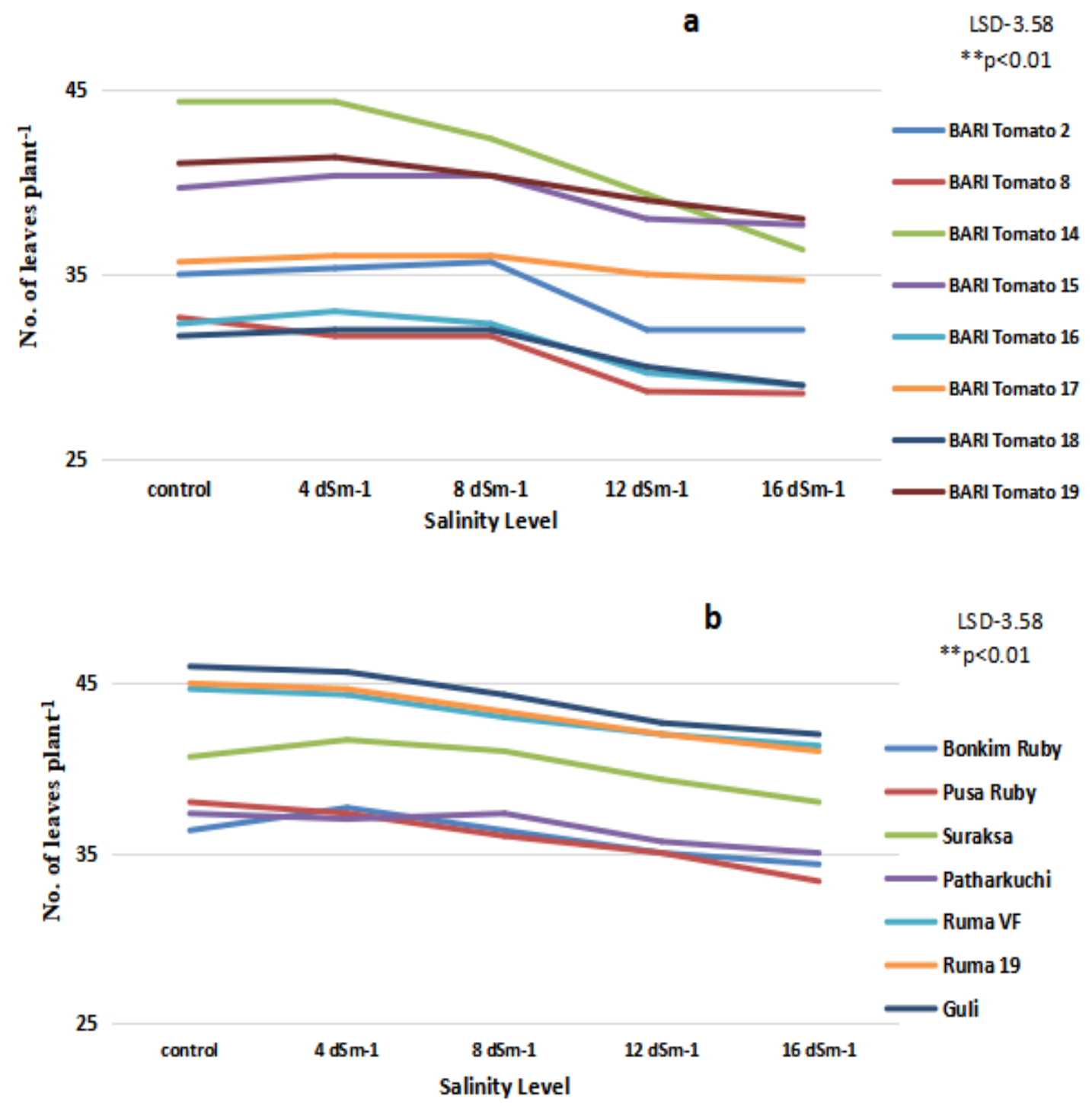

Fig. 3. Effect different levels of salinity on selected varieties of tomato in respect of number of leaves, a) BARI released variety, b) Local variety

\section{Effect of Salinity on Leaf Length}

There were significant variations due to different salinity levels in respect of length of leaves. The maximum leaf $(33.1 \mathrm{~cm})$ was found in $4 \mathrm{dSm}^{-1}$ which was statistically similar to control (32.9) and 8 $\mathrm{dSm}^{-1}(32.8 \mathrm{~cm})$ and the shortest leaf $(31.0 \mathrm{~cm})$ in $16 \mathrm{dSm}^{-1}$ (Figure 1c). The maximum length of leaves $(39.6 \mathrm{~cm})$ was recorded from the variety BARI Tomato-15 with the control which was statistically similar to BARI Tomato -15 up to $16 \mathrm{dSm}^{-1}$. The lowest length of leaves $(27.9 \mathrm{~cm})$ was found in Patharkuchi with $16 \mathrm{dSm}^{-1}$ (Figure 4). Shalhevet (1994) also noted that leaf length decreased under high salinity conditions. Length of leaves decrease after $6 \mathrm{dSm}^{-1}$ salinity and differ significantly among various tomato cultivars (Rahman et al. 2018). 


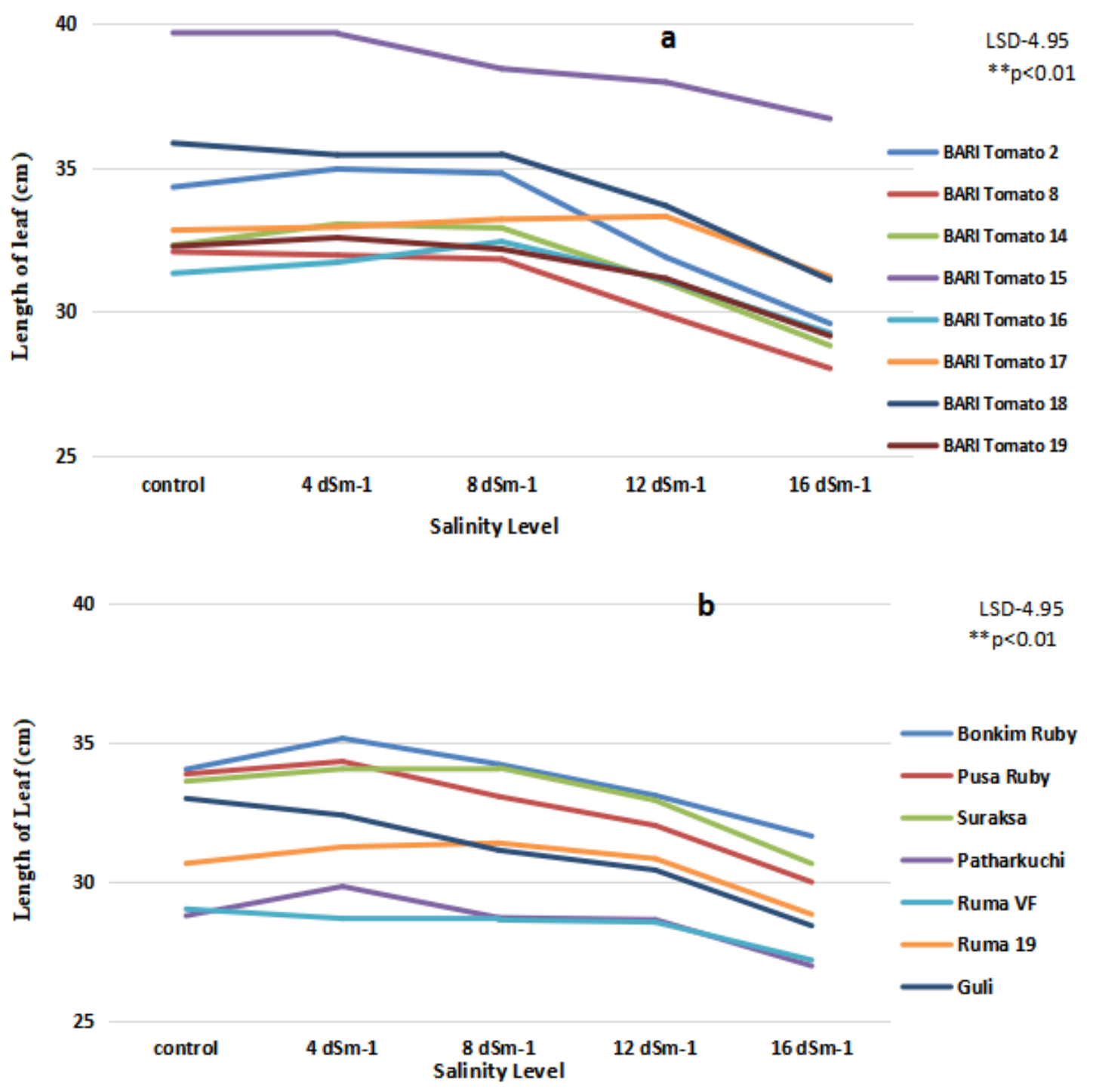

Fig. 4. Effect different levels of salinity on selected varieties of tomato in respect of length of leaf, a) BARI released variety, b) Local variety

\section{Effect of Salinity on Leaf Breadth}

There was a significant variation in leaf breadth due to different salinity levels. The broadest leaf (33.2 $\mathrm{cm}$ ) was recorded from the control which was followed by $4 \mathrm{dSm}^{-1}(32.6 \mathrm{~cm})$ and the narrowest leaf $\left(29.3 \mathrm{~cm}\right.$ ) in $16 \mathrm{dSm}^{-1}$ (Figure 1d). Significant variation in leaf breadth was also found for the combination of varieties and salinity levels (Figure 5). The highest breadth of leaf $(38.3 \mathrm{~cm})$ was recorded from the variety BARI Tomato- 16 with the control followed by BARI Tomato-16 with 4 $\mathrm{dSm}^{-1}$. The lowest breadth of leaves $\left(25.2 \mathrm{~cm}\right.$ ) was obtained from the variety Pusa Ruby with $16 \mathrm{dSm}^{-1}$ salinity level. After $6 \mathrm{dSm}^{-1}$ the breadth of leaf adversely affect by salinity (Rahman et al. 2018). Shalhevet, (1994) also stated that, the leaf breadth reduced in high saline condition. 


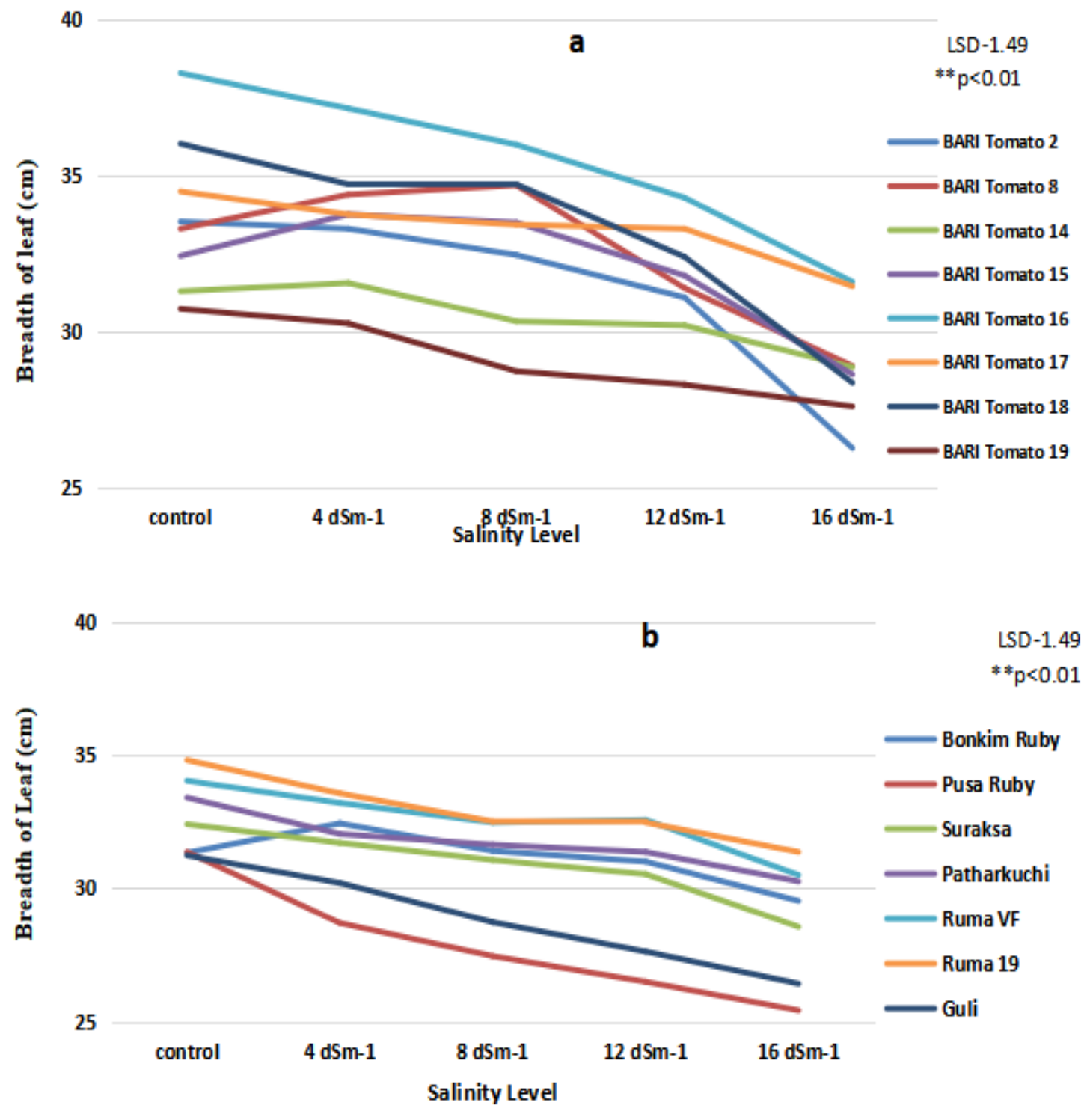

Fig. 5. Effect different levels of salinity on selected varieties of tomato in respect of breadth of leaf, a) BARI released variety, b) Local variety

\section{Effect of Salinity on the Number of Fruits Plant ${ }^{-1}$}

Different salinity levels had a significant effect on the number of fruits plant ${ }^{-1}$ (Figure 1e). The maximum number of fruits plant ${ }^{-1}(14.4)$ were observed in $4 \mathrm{dSm}^{-1}$ which was statistical similar to the control (14.4) followed by the $8 \mathrm{dSm}^{-1}$ (12.9). The minimum number of fruits plant ${ }^{-1}$ was found in 16 $\mathrm{dSm}^{-1}$ (9.5). The combined effect of variety and salinity level was also found significant in the case of number of fruits per plant (Figure 6). The maximum number of fruits plant $^{-1}$ (22.6) was found in Ruma19 with control which was statistically similar to BARI Tomato-16 with control (20.6) and that was the minimum (4.3) in BARI Tomato-17 with $12 \mathrm{dSm}^{-1}$ and $16 \mathrm{dSm}^{-1}$. Ahmad et al. (2019) also stated that number of fruits plant ${ }^{-1}$ decrease with increasing salinity level. Similar results were found by Islam et al, 
(2011) and Umar et al, (2018) who reported that fruit number of tomato decreased with increasing salinity and different genotypes of tomato showed different fruit numbers in respect to salinity.

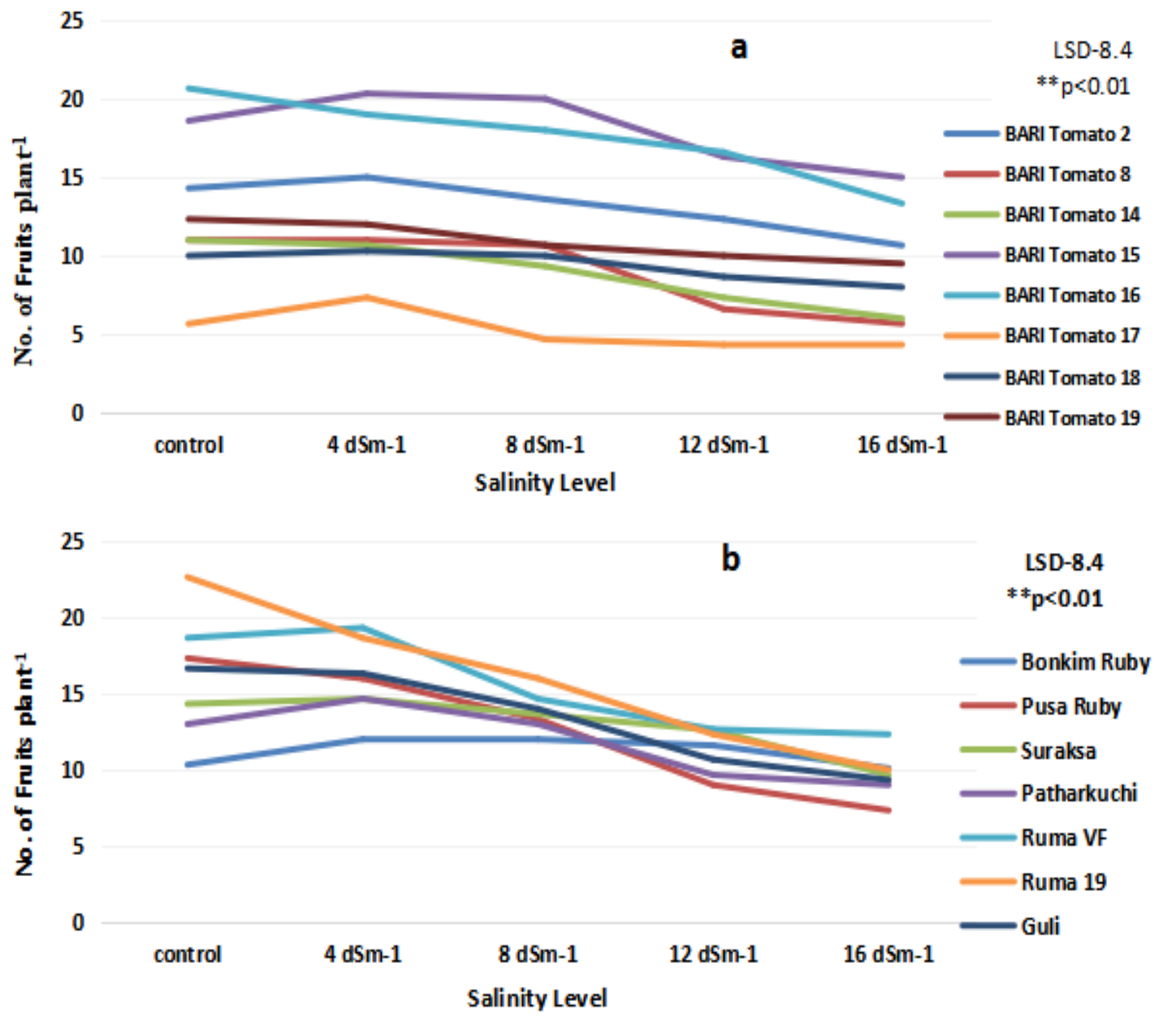

Fig. 6. Effect different levels of salinity on selected varieties of tomato in respect of number of fruits per plant, a) BARI released variety, b) Local variety

\section{Effects of Salinity Level on Weight of Fruits per Plant}

Significant variations were found in different salinity levels in respect of weight of fruits per plant (Figure 1f). The maximum weight of fruits plant ${ }^{-1}(422.5 \mathrm{~g})$ was observed in $4 \mathrm{dSm}^{-1}$ which was statistical similar to the control $(415.8 \mathrm{~g})$ followed by the $8 \mathrm{dSm}-1(369.0 \mathrm{~g})$. The minimum weight of fruit plant ${ }^{-1}$ was found in $16 \mathrm{dSm}^{-1}(262.46 \mathrm{~g})$. The combined effect of variety and salinity levels was also found significant in weight of fruits plant $^{-1}$ (Figure 7). The maximum weight of fruits plant ${ }^{-1}$ $(708.0 \mathrm{~g})$ was found in BARI Tomato- 15 with $4 \mathrm{dSm}^{-1}$ that was statistically similar to BARI Tomato15 with $8 \mathrm{dSm}^{-1}(681.0 \mathrm{~g})$ and control $(656.3 \mathrm{~g})$ and the minimum (132.6) in Ruma-19 with $16 \mathrm{dSm}^{-1}$ salinity levels. Reduction of yield of tomato by salinity is due to the reduction of number of fruit rather than fruit size (Pengfei et al., 2017). The number of fruits per plant and fruit weight decreased with increasing salinity (Cho et al., 1996; Moniruzzaman et al., 2013 and Rahman et al., 2018). In later stages, salinity reduces yield by affecting growth parameters (Karim et al. 1993). In pot soil, the pH, Organic matter $(\mathrm{OM}), \mathrm{Na}, \mathrm{K}, \mathrm{Ca}$, and $\mathrm{P}$ increase with salinity but the total nitrogen $(\mathrm{N})$ decrease and 
finally halves the fruit production (Rahman et al. 2018). The addition of salt solution to the pot soil might have deleterious effects on the physico-chemical properties of the soil (Fontes and Ronchi 2002).
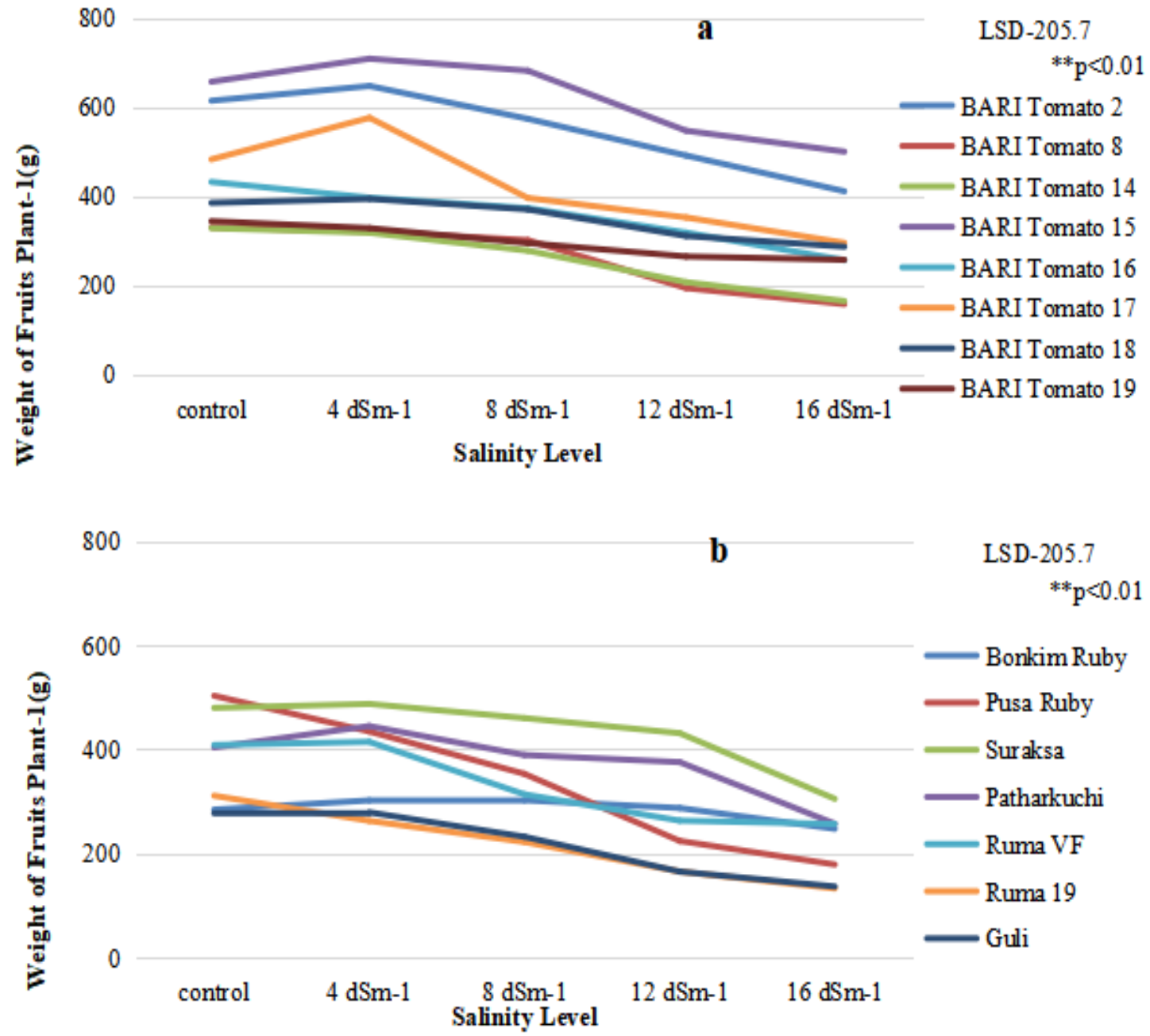

Fig. 7. Effect different levels of salinity on selected varieties of tomato in respect of weight of fruits plant $^{-1}$, a) BARI released variety, b) Local variety

\section{Average performance of the variety}

The varieties used in the trial showed significant differences in growth and yield characteristics. Guli was the tallest variety and BARI tomato- 2 was the shortest one. The variety with the highest number of leaves was found in Guli while lowest number of leaves in BARI Tomato-8. In terms of leaf length, BARI Tomato-15 had the longest leaves and Ruma VF produced the shortest one. The narrowest leaves were found in Ruma VF and the widest leaves recorded from BARI Tomato 15. BARI Tomato 15 had the highest number of fruits and BARI Tomato 17 had the least number of fruits which was one third of BARI Tomato 15. The highest fruit yield was recorded in BARI tomato 15 and the lowest in Guli (Figure 8). 


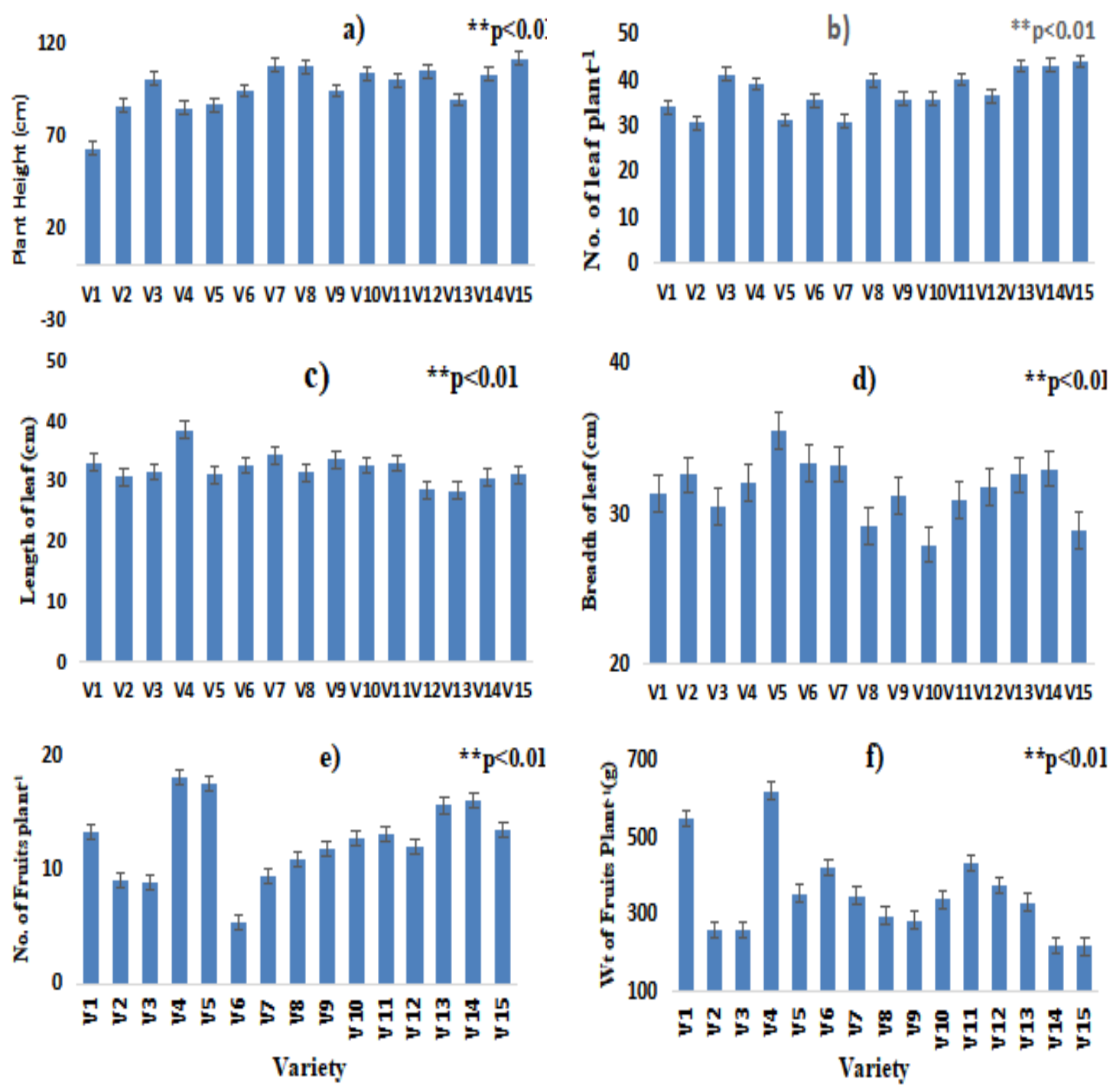

$\mathrm{V}_{1}$. BARI tomato 2, $\mathrm{V}_{2}$. BARI tomato 8, $\mathrm{V}_{3}$. BARI tomato14, $\mathrm{V}_{4}$. BARI tomato $15, \mathrm{~V}_{5}$. BARI tomato16, $\mathrm{V}_{6}$. BARI tomato17, $\mathrm{V}_{7}$. BARI tomato18, $\mathrm{V}_{8}$. BARI tomato 19, $\mathrm{V}_{9}$. Bonkim Ruby, $\mathrm{V}_{10}$. Pusa Ruby, $\mathrm{V}_{11}$. Suraksa, $\mathrm{V}_{12}$. Patharkuchi, $\mathrm{V}_{13}$. Ruma VF, V14. Ruma 19, $\mathrm{V}_{15}$. Guli

Fig. 8. Average performance of tomato varieties in respect of growth and yield traits, a). Plant height, b) Leaves plant $\left.{ }^{-1}, c\right)$. Leaf length and d). Leaf breadth, e). Fruits plant $^{-1}$ and f). Fruit weight plant $^{-1}$

\section{Conclusion}

The results showed that both tomato genotypes and salinity treatments were significantly different from the agro-morphological traits of tomato plants. Higher salinity levels were not suitable for plant height, number of leaf, length of leaf, breath of leaf, fruits plant $^{-1}$ and weight of fruits plant ${ }^{-1}$. Local tomato variety Guli gave the better plant height up to $124 \mathrm{dSm}^{-1}$. Tomato var. BARI tomato 15 gave highest fruit weight per plant up to $8 \mathrm{dSm}^{-1}$. This could be a very good opening point for advance research on salinity-tolerant varieties. 


\section{Acknowledgements}

The authors are grateful to the Bangobondhu Fellowship Trust for financial support to conduct the study.

\section{References}

Ahmad, M., A. Shoukat, M. Anjum, M. Kamran, M. Q.Saeed, R. Hussain, M. H. Abbas and Y. Shafiq. 2019a. Assessment of tomato genotypes against salinity on the basis of morphological and physiological parameters in hydroponic conditions. Nat. Sci., 17 (2): 56-70. http://www.sciencepub.net/nature, doi:10.7537/marsnsj170219.06.

Ahmad, R., S. Hussain, M.A. Anjum, M.F. Khalid, M. Saqib, I. Zakir, A. Hassan, S. Fahad, S. Ahmad, 2019b. Oxidative stress and antioxidant defense mechanisms in plants, under salt stress in plant abiotic stress tolerance. Springer: 191-205.

Al-Daej, M.I. 2018. Salt tolerance of some tomato (Solanum lycopersicum L.) cultivars for salinity under controlled conditions. Ame. J. Pl. Phy. 13: 58-64.

Ashraf, M. and A. Wahed. 1993. Response of some genetically divers lines of chickpea to salt. Aust. J. Pl. Phys., 154: 257-266. https://www.jstor.org/stable/42939026.

Bose, T.K. and. M.G. Som. 1990. Vegetable crops in India. Published by B. Mitra and Naya Prokash, 206, Bidlran Sarani, Calcutta, India, pp.241-249.

Boyer, J.S. 1982. Genetic Plant productivity and the environment. Science, 218: 443-448.

Cho J.Y., S.J. Chung and A. Feigin. 1996. Interactive effects of saline on photosynthesis and related growth parameters in tomatoes. pp.549-554.

Estan, M.T., M.M. Martinez-Rodriguez, F. Perez-Alfocea, T.J. Flowers, M.C. Bolarin. 2005. Grafting raises the salt tolerance of tomato through limiting the transport of sodium and chloride to the shoot. J. Exp. Bot. 56: 703-712.

Fontes, P.C.R. and C.P. Ronchi. 2002. Critical values of nitrogen indices in tomato plants grown in soil and nutrient solution determined by different statistical procedures. Pesq. Agropec. Bras. 37: 14211429

Gomez, K.A. and A.A. Gomez. 1984. Statistical Procedures for Agricultural Research. (2nd edn.). John Wiley and Sons, New York, USA, pp: 1-340.

Hassan, M.M., T.A. El-Masry, and A.A. Abou-Arab. 1999. Effect of soil salinity on growth, yield and elemental concentrations in tomato. Egt J. Hort. 26(2): 187 - 198.

http://www.fao.org/soils-portal/soil-management/management-of-some-problem-soils/salt-affectedsoils/more-information-on-salt-affected-soils/en/.

Islam M.A., M.M. Rahman, M. Bodrud-Doza, M.I. Muhib, M. Shammi and A. Zahid. 2018. A study of groundwater irrigation water quality in south-central Bangladesh: a geo-statistical model approach using GIS and multivariate statistics, Acta Geochim, 37: 193-214.

Islam M. A., A. Zahid, M.M. Rahman, M.S. Rahman, M.J. Islam, Y. Akter. 2016. Investigation of groundwater quality and its suitability for drinking and agricultural use in the south central part of the coastal region in Bangladesh, Expo. Health, 9: 27-41.

Islam, M.T., M.I. Aral, M.A. Hossain, A.K. Sen and R.K. Dutta. 2011. Identification of tomato genotypes for salt tolarence, In. J. Sust. Crop prod. 6(1): 17-21.

Javed, A., U.H. Tanveer and S. Muhammad. 2002. Effect of salinity on yield, growth and nutrient contentment of tomato, Pak. J. Agric. Sci. 39(2): 76-79.

Karim M.A., E. Nawata, and S. Sigenaga. 1993. Effects of salinity and water stress on the growth, yield and physiological characteristics in hexaploid triticale, Jpn. J. Trop. Agric., 37: 46-52

Karim Z., S.G. Hussain and M. Ahmed. 1990. Salinity problems and crop intensification in the coastal regions of Bangladesh, BARC, Dhaka. 
Mahajan, S. and N. Tuteja. 2005. Cold, salinity and drought stresses: an overview. Arch. Biochem. Biophysics, 444(2): 139-158. doi: 10.1016/j.abb.2005.10.018.

Moniruzzaman, M., M.N. Islam, M.F.B. Hossain, M.M. Rashid and K.U. Ahamed. 2013. Evaluation of tomato germplasm against salinity. Bul. Ins. Trop. Agric., Kyushu Univ. 36: 9-16.

Parvaiz, M. 2014. Response of Maize to salt stress a critical review. Int. J. Healt. Sci. (IJHS), 1(1): 13-25.

Pengfei, Z., M. Masateru and D. Yanyan. 2017. Effects of salinity stress at different growth stages on tomato growth, yield and water use efficiency. Communications in Soil Science and Plant Analysis. The United Graduate School of Agricultural Sciences, Gifu University, 1-1 Yanagido, Japan. pp.5011193. doi.org/10.1080/00103624.2016.1269803.

Pompeiano, A., E. Di Patrizio, M. Volterrani, A. Scartazza, L. Guglielminetti. 2016. Growth responses and physiological traits of seashore paspalum subjected to short-term salinity stress and recovery. Agr. Water Manag. 163: 57-65. doi: 10.1016/j.agwat.2015.09.004.

Rahman, M.M., M. Hossain, K.F.B. Hossain, M.T. Sikder, M. Shammi, M. Rasheduzzaman, M.A. Hossain, A.M. Alam and M.K. Uddin. 2018. Effects of NaCl-Salinity on Tomato (Lycopersicon esculentum Mill.) Plants in a Pot Experiment. Open Agric. 3: 578-585.

Shalhevet, J. 1994. Using water of marginal quality for crop production. Major issues, Agric. Wat. Mang. 25(3): 233-269. doi.org/10.1016/0378-3774 (94)90063-9.

Shammi M., B. Karmaker, M.M. Rahman, M.S. Islam, R. Rahman and M.K. Uddin. 2016. Assessment of salinity hazard of irrigation water quality in monsoon season of Batiaghata Upazila, Khulna District, Bangladesh and adaptation strategies, Pollution, 2: 183-197.

SRDI. 2010. SRMAF Project. Soil Resource Development Institute. Ministry of Agriculture. Government of the People's Republic of Bangladesh. pp. 1-60.

Umar, J., A. Aliyu, K. Shehu and L. Abubakar. 2018. A Study on Effects of Salinity on Growth and Yield of Tomato Genotype (Solanum lycopersicum), Sust. Food Prod. 3:16-24. doi: 10.18052/www.scipress.com/SFP.3.16.

Yadav, R., K.R. Chaturvedi, Dubey, Sarwan, P.K. Joshi and P. Minhas. 2003. Potentials and hazards associated with sewage irrigation in Haryana, In. J. Agric. Sci. 73: 249-255.

Yeo, A.R., S.J.M. Capcorn and T.J. Flowers. 1985. The effect of salinity upon photosynthesis in rice (Oryza sativa L.): gas exchange by individual leaves in relation to their salt content, J. Exp. Bot. 36: 12401248. 